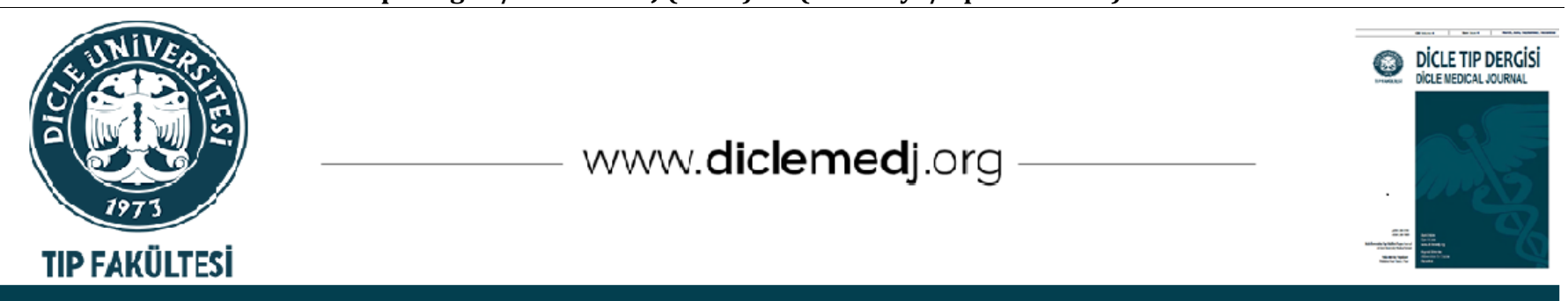

Derleme / Review

\title{
Pediatrik COVID-19 ve Yaklaşımı
}

\author{
Fesih Aktar ${ }^{D} 1$, Halil Sağır ${ }^{\text {i }} 1$ \\ 1 Dicle Üniversitesi Tıp Fakültesi, Çocuk Sağlığı ve Hastalıkları Anabilim Dalı, Diyarbakır, Türkiye \\ Geliș: 29.09.2021; Kabul Tarihi: 29.09.2021
}

Öz

SARS-CoV-2 (Koronavirüsün neden olduğu ciddi akut solunum yetmezliği sendromu) enfeksiyonunun klinik ve demografik özelliklerine ilişkin pediatrik popülasyon ile ilgili çalışmalar sınırlıdır. Pnömoni çocukluk çağı yaş gruplarında ciddi mortalite nedeni olup, bu yazıda SARS-CoV-2 enfeksiyonuna ait gelişen klinik bulguları ve pandemi süresince üniversitemiz hastanesinde çocukluk çağı pandemi yönetimini sistemik olarak derlemeyi amaçladık.

Anahtar kelimeler: çocuk, pandemi, koronavirüs, yönetim

\section{Pediatric COVID-19 And Its Approach}

\begin{abstract}
Studies on the clinical and demographic characteristics of SARS-CoV-2 (Severe Acute Respiratory Syndrome causing Coronavirus) infection in the pediatric population are limited. Pneumonia is a serious cause of mortality in childhood age groups, and we aimed to systematically review the clinical findings of SARS-CoV-2 infection and the management of childhood pandemics in our university hospital during the pandemic.
\end{abstract}

Keywords: child, pandemic, coronavirus, management.

DOI: 10.5798/dicletip.1005406

Yazışma Adresi / Correspondence: Fesih Aktar, Dicle Üniversitesi Tıp Fakültesi, Çocuk Sağlı̆̆ı ve Hastalıkları Anabilim Dalı, Diyarbakır, Türkiye e-mail: fesihaktar@yahoo.com 


\section{GíRiş}

\section{Koronavirüs'ün Tarihçesi}

Koronavirüs ilk olarak 1937 yllında Beaudette ve Hudson tarafindan tavuklarda üst solunum yolu enfeksiyonuna yol açan koronavirüs tanımlanmıştır ${ }^{1}$. İnsan da ise soğuk algınlığı geçiren bir hastada 1960 yllında ilk olarak tanımlanmıştır². Dünya Sağlık Örgütü (DSÖ), 2020 'de SARS-CoV-2 Koronavirüs'ün neden olduğu hastalığı coronavirus disease-19 (COVID-19) olarak adlandırmıştır ${ }^{3}$.

\section{KORONAVİRÜS'ÜN GENEL ÖZELLIKLERİ}

Koronavirüsler, Coronaviridae ailesinden Orthocoronavirinae alt ailesi içerisinde bulunmaktadır. Koronavirüs ailesi sığır, kedi ve deve gibi memelilerde ve kuşlarda hastalığa neden olan helikal yapıda pozitif polariteli bir RNA virüs ailesidir. Koronavirüs şu ana kadar saptanmış en büyük RNA virüs olarak bilinmektedir ve şekil olarak taç yapısına benzediğinden dolayı 'corona' adını almıștır4.

\section{BULAŞMA YOLLARI}

Virüs temel olarak hayvandan insana enfekte hayvanın yenmesiyle bulaşmaktadır. Daha sonra enfekte kişi ile yakın temas sonrası bulaş göstermektedir. Esas bulaş yolu damlacık yoludur bulaştır. Enfekte kişilerin öksürme hapşırma yoluyla ortaya saçılan virüsler ayrıca çevreye karşı lokalizasyon göstermekte ve elle temas sonrasında elin ağız, burun ve göz mukozası temas sonrası bulaş göstermektedir 5 . TANI

Günümüzde SARS-CoV-2 tanısının konulmasında iki temel yol vardır. İlk olarak viral antijenlerin ve viral RNA'nın saptanması, ikincisi ise serolojik olarak yapılan testlerdir. COVID-19 için ilk önerilen test revers transkripsiyon-polimeraz zincir reaksiyonu (RT-PCR) ile yapılan tanı testidir ${ }^{6}$. Viral RNA testleri orofarenks, nazofarenks sürüntülerinde yapılabildiği gibi bronkoalveolar lavaş sıvısında ve balgamda da yapılabilmektedir. Fakat yapılan bir çalışmaya göre nazofarenksten alınan örneğin orofarenkse göre 2 kat daha anlamlı olduğu gösterilmiştir7.

\section{KLİNIKK}

Pandeminin başından itibaren dünyadan ve ülkemizden elde edilen bilgilerde çocukluk çağı koronavirüs enfeksiyonunun klinik tablosunun daha hafif olduğu görülmektedir8,9. Çocukluk çağı COVID-19 hastalığını klinik duruma göre sınıflandırdığımızda beş gruba ayırabiliriz ${ }^{9}$.

Asemptomatik enfeksiyon: Hastanın herhangi bir klinik bulgusunun olmaması ve görüntülemenin normal olmasına karşın SARSCoV-2 testinin pozitif olması durumudur.

Hafif enfeksiyon: Üst solunum yolu etkilenmesine bağlı olarak ateș, yorgunluk, kas ağrısı, öksürük ve burun akıntısı görülmekle beraber akciğer tutulumu beklenmez.

Ilıml enfeksiyon: Pulmoner etkilenmenin başladığı grup olarak değerlendirilir. Dirençli ateş, kuru öksürük (balgamlı öksürüğe dönüşebilir), fizik muayenede wheezing, ral ve ronküs duyulabilir. Bazı hastalar klinik olarak asemptomatik olurken akciğer tomografisinde pulmoner etkilenme görülmektedir.

Ciddi enfeksiyon: İlk olarak akciğer etkilenmesi olması, ardından gastrointestinal sistem etkilenmesi ile beraber diyare görülmektedir. Solunumsal olarak hastalarda dispne ve hipoksemi görülmektedir.

Kritik enfeksiyon: Bu hastalar akut respiratuar distres ve solunum yetmezliği ile seyreden hasta grubu olarak değerlendirilir. Bununla beraber şok, ensefalopati, akut böbrek yetmezliği miyokardiyal etkilenme ve multiorgan yetmezliği ile seyreden gruptur. 
Dünya genelinde çocukluk çağı COVID-19 çalışmalarına bakıldığında; Çin hastalık kontrol merkezinde kayıtlı 2134 pediatrik hastada yapılan bir çalışmada \%4,4 hastada asemptomatik, $\% 50,8$ 'inde hafif düzeyde, $\% 38,8^{\prime}$ inde orta şiddetli ve $\% 5,8^{\prime}$ inde ise ciddi ve kritik düzeyde hastalık gelişti ve sadece 14 yaşındaki bir hastada ölüm rapor edildi ${ }^{9} .171$ pediatrik COVID-19 vakalarının incelendiği başka bir çalışma da hastaların \%15,8'i asemptomatik ve \%19,3'ünde ise üst solunum yolu bulguları izlenmekteydi ${ }^{10}$.

\section{Laboratuvar}

COVID-19 hastalarında belirgin bir laboratuvar bulgusu olmasa da pandemi süresince hem erişkin hem de çocuk hastalar için birçok hemogram ve biyokimyasal parametreler hastalığın tanı, takip ve prognostik değerleri açısından araştırılmıştır. Özetle, çocuk hastaların COVID-19 enfeksiyon takibinde lenfopeni, trombositopeni, ferritin ve d-dimer yüksekliği, prokalsitonin ve C-reaktif protein (CRP) düzeylerinin ölçülmesi en çok çalıșllan parametrelerdir ${ }^{11}$. Çocukluk çağı COVID-19 hastalığında her ne kadar lenfopeni ön planda olsa da hastalarda lökositoz varlığının bakteriyel veya süperenfeksiyon göstergesi olabileceği de göz önünde bulundurulmalıdır. Trombositopeni ve d-dimer yüksekliği ise hastalarda kötü prognoz göstergesi olarak kabul edilir. Akut faz reaktanı olan C-reaktif proteini sıklıkla artmakta olup prokalsitonin ise yoğun bakım ünitesinde olan hastalarda artış göstermektedir ${ }^{10}$. Laboratuvarda ayrıca diğer artış gösterebilen parametreler laktat dehidrogenaz, alanin transaminaz, bilirübin ve kreatin olup, kan albümin düşüklüğü de kötü prognoz göstergesi olarak değerlendirilmektedir ${ }^{12}$. Bunların dışında organ yetmezlikleri de gelișebildiğinden başta böbrek ve kalp fonksiyonları olmak üzere sistemlere yönelik kan tetkikleri istenmelidir ${ }^{12}$.

\section{Görüntüleme}

Çocukluk çağında COVID-19 enfeksiyonu nedeniyle başvuran hastaların büyük çoğunluğu asemptomatik, hafif veya llıml vakalar olduğundan belirgin solunum semptomu olmayan hastalar dışında akciğer tomografisi (BT) erişkin hastalardan farklı olarak ilk başvuru da önerilmemektedir. Hastalığı erken evrelerinde akciğer grafisi normal yada hafif pnömoni benzeri bulgular gösterebilir. Ancak ciddi vakalarda direkt grafide genellikle tek taraflı veya bilateral periferik alanları etkileyen düzensiz, multifokal yamasal buzlu cam akciğer opasiteleri, konsolidasyonlar ve interstisyel değişiklikler görülebilir ${ }^{13}$. Düşük doz uygulanması önerilmekle birlikte akciğer tomografisi çekilen vakalarda ise belirgin olan bulgular buzlu cam ve/veya segmental konsolide alanlardır ${ }^{13,14}$.

\section{Çocukluk Çağı COVID-19 Özel Durumu (MIS- c)}

İlk olarak Nisan 2020'de İngiltere'de, ardından ABD olmak üzere dünyanın birçok yerinden COVID-19 enfeksiyonu ile ilişkili olduğu düşünülen inkomplet Kawasaki hastalığına veya toksik şok sendromuna benzeyen vakalar bildirilmeye başlanmıştır. Bu durum çocukluk çağında COVID-19 ile olası iliş̧kili çoklu sistemik inflamatuvar sendrom (MIS-c) olarak tanımlanmıştır (14,15). MIS-c vaka tanımı aşağıdaki kriterlere göre yapılmaktadır ${ }^{15,16}$;

\section{0-21 yaş arası ve}

2. 24 saatten uzun süren, $>38.0^{\circ} \mathrm{C}$ ölçülmüş veya ailenin ateş varlığını bildirimi ve

3. Laboratuar tetkiklerinde inflamasyon kanitı (en az 2 veya daha fazla kanıt varlığı) (yüksek prokalsitonin, sedimantasyon, CRP, D-dimer, fibrinojen, ferritin, laktat dehidrogenaz, IL-6 seviyeleri ile artmış nötrofil sayısı, düşük lenfosit sayısı ve düşük albumin düzeyi) ve

4. Hastane yatışı gerektirecek kadar ağır hastalık varlığı ve 
5. Birçok organ sisteminde tutulum (en az $\geq 2$ tutulum) ve

6. Miyokardit ile ilişkili enfeksiyonlar (bakteriyel sepsis, enterovirüs enfeksiyonu gibi), streptokoksik veya stafilokoksik toksik şok sendromları gibi alternatif başka tanıların olmaması ve

7. Yeni geçirilmekte olan veya geçirilmiş veya COVID-19 enfeksiyon kanıtı

Hastalığın tedavisi altta yatan başka bir hastalığın varlığına göre değișebilmekle birlikte antibiyoterapi, yakın kardiyak monitörizasyon, sıvı elektrolit tedavisi ile Kawasaki kriterlerini karşılayan olgularda intravenöz immunoglobulin (IVIG) ve aspirin önerilmektedir ${ }^{15}$.

\section{Yenidoğanda COVID-19 Enfeksiyonu}

COVID-19 enfeksiyonlu bebeklerde klinik belirtiler büyük çocuklardaki gibi asemptomatik, hafif veya şiddetli bir seyirde olabilir. Yenidoğan COVID-19 enfeksiyonunda inkübasyon periyodu ortalama 3-7 gündür ${ }^{16,17}$. Enfeksiyon tanısı, üst veya alt solunum yollarından alınan sürüntü numunesinde PCR testi pozitifliği ile konur ${ }^{16,18}$. Yenidoğanlarda COVID-19 enfeksiyonunun olası bulaş yolları; anneden fetüse vertikal geçiş, yakın temas, damlacık yoluyla (aile fertleri veya ziyaretçiler) bulaş ve hastane kaynaklı olarak sayılabilir. Vertikal bulaş, genellikle anne karnında iken plasenta aracılığı ile, doğum sirasında sekresyonların aspirasyonu ve doğum sonrası anne sütü ile oluşabilmektedir ${ }^{17,18}$.

COVID-19'un fetal sonuçları ile ilgili çalışmalar devam etmektedir. Çin'de dokuz gebenin alındığı bir vaka çalışmasında anneden bebeğe vertikal geçiş (amniyon sıvısı, yenidoğan boğaz sürüntüsü numunesi, kordon kanı ve anne sütü numunelerinin incelenmesi sonucunda virüse rastlanılamamıştır) gösterilememiştir ${ }^{18}$. Ancak literatürde vertikal geçişi gösteren bazı vakalar da bildirilmiştir ${ }^{17,18}$. Şüpheli ve kesin COVID-19 tanılı gebelerin doğumu, deneyimli personel eşliğinde, etkili izolasyon önlemleri alınmış doğum salonu veya ameliyathanelerde yapılmalıdır. COVID-19 enfeksiyonun vertikal geçiş riskini azaltmak için göbek kordonunun geç klemplenmesi önerilmez. Doğum sonrası yenidoğanda resüsitasyon ihtiyacı gelişmesi halinde işlem 'Yenidoğan Resüsitasyon Programına' göre yapılmalıdır16. Yenidoğan resüsitasyon işlemi doğum salonunda gerçekleştirilmeli ve bebeğin bu amaçla transfer edilmesinden kaçınılmalıdır. Doğum sonrasında anne ve yenidoğanın şikâyetlerine göre anne ve bebeğin takibi yapılır. Bu süre zarfında bebeğin açlk yatak yerine küvözde takip edilmesi uygundur (16). Yenidoğan, doğum sonrasında asemptomatik ve şüpheli enfeksiyon olarak tanımlanan annenin genel durumu iyi ise, yenidoğan anne yanına alınarak semptom takibi yapilır. Annenin test sonucu negatif ise rutin olan yenidoğan bakımına devam edilir. Anne pozitif ise bebek de COVID-19 açısından test edilir. Bebek negatif veya pozitif olsun olmasın anne asemptomatik ise bebek gerekli önlemler alınarak aynı odada izole edilebilirler. DSÖ, bu hususta anne ve bebeğin birlikte kalmalarını, özellikle doğumdan hemen sonra ve emzirme sirasinda ten tene temas uygulamaları sağlanmasını önermektedir ${ }^{17}$. Yenidoğan bebeğin test sonucu pozitif ise tedavisi yenidoğan tedavi yönetimine uygun olarak izolasyon kuralları ile birlikte yürütülür. Yenidoğanlarda COVID-19 șüphesi gösteren klinik durumlar varsa ileri tedavilerinin mümkünse tek kişilik ve negatif basınçlı izolasyon odalarında yatırılarak sağlanması uygundur ${ }^{16}$.

Yenidoğanda COVID-19 enfeksiyonuna ait klinik bulgular özellikle prematürelerde spesifik değildir. Bundan dolayı vakaların vital bulgularının, solunum ve gastrointestinal semptomlarının yakından izlenmesi gerekir. COVID-19 ile enfekte olmuş bir yenidoğanın vücut sıcaklığı normal, düşük veya yüksek 
olabilir. Bebeklerde emmede azalma, solunum semptomları (burun kanadı solunumu, solunum eforu, apne, takipne, öksürük), taşikardi, letarji, ishal, kusma, abdominal distansiyon gelișebilir. Laboratuvar bulguları büyük çocuklardaki gibi spesifik olmayabilir ve benzer sonuçlar ortaya çıabilirir6-18.

DSÖ, şüpheli, olası veya kesin COVID-19 ile enfekte annelerin emzirmeye başlaması, devam etmesi ve ten tene temas uygulaması için teşvik edilmesini önermektedir. Annenin genel sağlık durumu doğrudan emzirmeye engel teşkil ediyorsa, dezenfeksiyon kuralları uygulanarak pompa ile anne sütünün sağılması desteklenmelidir. Bebeğin anneden ayrılması veya annede depresyon varlığında aile desteği mutlaka sunulmalıdır. Hastalığın yenidoğanda etkin ve etkili bir tedavisi halen bulunmamaktadır. Enfekte yenidoğanlarda özellikle geniş spektrumlu antibiyotiklerin uygunsuz veya gereksiz kullanımından sakınılmalıdır. Öncelikli tedavi yakın izlem ve destekleyici bakımdır ${ }^{16-18}$.

\section{Çocuklarda COVID-19 Tedavisi}

Çocuklarda COVID-19 enfeksiyonu tedavisinde halen etkinliği kanıtlanmış bir ajan bulunmamaktadır. Ancak dünya ve ülkemiz verileri incelendiğinde elde edilen bulgular eşliğinde halen destek tedavilerinin birçok vakada yeterli olduğu görülmektedir. Çocukluk çağı COVID-19 tanısı alan çocuklarda altta yatan veya eşlik eden kronik hastalıklar hastalığın seyri ve ağırlı̆̆ açısından önemlidir. Bu nedenle, nadir de olsa bu grup hastaları izleyen hekimlerin klinik ve tedavi kararı verirken vakaları erişkin çalışmalarına göre değerlendirmesi ve planlanması uygun bir yaklaşım olacaktır. Tedavi her hasta özelinde değerlendirilmeli, verilecek ilaç veya antivirallerin yan etkileri ve uzun dönem sonuçları göz önünde bulundurulmalı ve olası ağır pnömoni bulguları ve risk faktörü olan çocuklarda ilaç tedavisi planlaması T.C. Sağlık Bakanlığı Halk Sağlığı Müdürlüğü COVID-19
Çocuk Hasta Yönetimi Rehberi doğrultusunda yapılmalıdır. Yoğun bakım ünitesine yatan, destek ve bakım tedavilerine rağmen organ fonksiyonlarinda bozulma olan veya devam eden kesin COVID-19 tanısı konmuş vakalarda antiviral tedavinin yanında makrofaj aktivasyon sendromu veya hemofagositoz sendromu gelişen hastalarda ise mutlaka ilgili branşa yönelik konsültasyonlar istenmeli ve tedavi yönetimi buna göre planlanmalıdır. Son zamanlarda çocuklarda MIS-c bildirilen vakalara bağlı daha ağır vakalar olsa da, COVID19 pandemisinin ilk dönemlerinden itibaren, dünya genelinde 0-9 yaş arasında kayıp çok az sayıda ve özellikle de erken yaşta bildirilmiştir. 10-19 yaş arasındaki çocuklarda ise ölüm oranı $\% 0,2$ olarak bildirilmiştir. $\mathrm{Bu}$ veriler ile çocuklarda klinik tablonun daha hafif ve mortalitenin daha az olduğu görülmektedir ${ }^{16,19}$.

COVID-19'lu çocuklarda ağrı veya rahatsızlı̆̆ın semptomatik tedavisi için steroid olmayan antiinflamatuvar ilaçlar (NSAID) kullanılabilir ${ }^{19}$. Çocuklarda influenza enfeksiyonu için antiviral tedavi önerileri COVID-19 pandemisi sırasında değişmemiştir. $\mathrm{Bu}$ iki durum birbiri ile sıklıkla karıștırıldığından, laboratuvar sonuçları beklenirken erken tedaviye başlamak için influenzaya yönelik antiviral tedavi de başlanabilir ${ }^{20}$.

Çeşitli ulusal komiteler tarafından önerildiği șekilde COVID-19'lu tüm pediyatrik hastalara destekleyici bakım sağlanmalıdır. Solunum desteği ve lüzum halinde antitrombolitik tedavi verilebilir. Ek oksijen ve solunum desteği (invaziv olmayan veya invaziv) dâhil olmak üzere solunum desteği sağlanması; solunum durumu semptomlardan yaklaşlk bir hafta sonra aniden değişebilir ${ }^{20}$.

Çocuklarda COVID-19 tedavisi için antiviral ajanların etkinliğini destekleyen kontrollü çalışmalardan elde edilen verilerin eksikliği göz önüne alındığında, antiviral ajanların kullanımına ilişkin çok merkezli geçici rehberin 
tavsiyelerine uyulduğu gibi, antiviral tedavinin vaka bazında düşünülmesi gerekmektedir ${ }^{21}$. Antiviral tedavi kullanma kararları, hastalığın ciddiyetine, klinik gidişata, mevcut etkililik kanıtlarına ve ilerleme riskini artırabilecek altta yatan koşullara göre kişiselleştirilmelidir. Birçok merkez ve klinik çalışmalarda antiviral ajan olarak Remdesivir kullanılmaktadır²,23. Amerika Birleşik Devletleri'nde Remdesivir, yetişkinlerde ve $\geq 12$ yaş ve $\geq 40 \mathrm{~kg}$ ağırlığındaki çocuklarda hastaneye yatırılmayı gerektiren COVID-19 tedavisi için ABD Gıda ve İlaç Dairesi (FDA) tarafından onaylanmıştır ${ }^{24}$.

\section{Remdesivir, ağırlığa göre şu şekilde dozlanır;}

3,5-40 kg: 1. günde $5 \mathrm{mg} / \mathrm{kg}$ intravenöz (IV) yükleme dozu, ardından her 24 saatte bir 2,5 $\mathrm{mg} / \mathrm{kg} \mathrm{IV}, \geq 40 \mathrm{~kg}: 1$. günde $200 \mathrm{mg}$ IV yükleme dozu, ardından her 24 saatte bir 100 mg IV

Ağır hastalığı olan çocuklar için olağan tedavi süresi 5 gün kadardır; 5 günden sonra iyileşmeyen kritik hastalığı olan çocuklar için Remdesivir 10 güne kadar uzatılabilir. Remdesivir İnfluenza'ya da etkili olduğundan dolayı ayrıca Oseltamivir kullanılması önerilmez ${ }^{24}$. Klinik bir araştırma bağlamı dışında, çocuklarda COVID-19 tedavisi için Hidroksiklorokin veya Klorokin kullanılması önerilmemektedir ${ }^{25}$.

Bir klinik araştırmaya katılamayan ciddi veya kritik COVID-19'lu seçilmiş çocuklar için (yani mekanik ventilasyona ihtiyaç duyanlar veya ek oksijene ihtiyaç duyanlar ve hastalığın ilerlemesi için risk faktörleri olanlar), düşük doz glukokortikoidler verilebilir ${ }^{26}$.

\section{Steroid doz hesaplamaları:}

Deksametazon: $0.15 \mathrm{mg} / \mathrm{kg}$ oral, IV veya nazogastrik (NG) günde bir kez (maksimum doz $6 \mathrm{mg}$ )

Prednizolon: $1 \mathrm{mg} / \mathrm{kg}$ oral veya günde bir kez NG (maksimum doz $40 \mathrm{mg}$ )
Metilprednizolon: $0.8 \mathrm{mg} / \mathrm{kg}$ IV günde bir kez (maksimum doz $32 \mathrm{mg}$ )

COVID-19 tedavisinde diğer antiviral tedaviler, Tocilizumab, monoklonal antikor tedavisi (Casirivimab-İmdevimab ve Sotrovimab) ile ilgili birçok çalışma olsa da mevcut haliyle çocukluk çağında yeterli klinik çalışma bulunmamaktadır.

\section{Evde İzlem Nasıl Olmalıdır?}

Hastalarda klinik takıp çok önemli olmakla beraber destekleyici tedavilerin alınması önerilir. Çin'de çocuklar üzerinde yapılan bir çalışmada bulaştırıcılık süresi yaklaşık olarak 11-20 gün arasında olup ortalama 15 gündür ${ }^{27}$. $\mathrm{Bu}$ hastalar yeterli D-vitamini almalıdır. Özellikle karantinaya alınıp yeterli güneş ışı̆̆ı görmeyen çocuklarda kullanılması önerilmektedir ${ }^{27}$.

\section{Uzun Dönem İzlemde Neler Yapılmalı?}

Taburculuk kriterlerini sağlayıp eve gönderilen hastalarda uzun dönem takip ile ilgili veriler hala sinırlıdır. Ancak enfeksiyonun multisistem tutulumu göz önünde bulundurulduğunda başta akciğer tutulumu olan hastalarda uzun dönemde gelişebilecek interstisyel ve restriktif akciğer hasarı açısından takip edilmeleri önemlidir. Hastaların böbrek fonksiyonları, kan parametreleri ve kardiyovasküler sistem bulguları belli periyotlarla takip edilmelidir. Altta yatan kronik hastalık, immün yetmezlik, enfeksiyon seyri sırasında MIS-c, hemofagositoz gelişmesi gibi durumlarla karşılaşan hastaların daha sıkı bir takip sürecinde olması ve gögüs fizyoterapisi, psikiyatrik destek gibi multidispliner bakım alması sağlanmalıdır.

\section{HASTANEMIZ PANDEMİ YÖNETIMİ VE ÇOCUK HASTA VERILLERIMIZ}

Ülkemizde Mart 2020'de ilk vakanın görülmesi ile birlikte hastanemizde de pandemi eylem planı uygulamaya konuldu. Üniversitemiz hastaneleri bünyesinde bulunan Kalp Hastanesi Il Pandemi Kurulu, üniversite ve hastane 
yönetimi kararlarınca pandemi hastanesi olarak hizmet vermeye başladı. Her ne kadar dünya ve ülke verilerinde çocuk hasta sayısının az olması bildirilse de, hastanemizin bölgemizin tek üniversite hastanesi olması, hem kendi il nüfusu hem de çevre illerdeki nüfus da göz önünde bulundurulduğunda yaklaşık 10 milyonluk bir hasta potansiyeline hizmet ettiği düşünüldüğünden bu bağlamda çocuk vakalarının bu büyük kitle içerisinde yüksek bir orana ulaşabileceği hesaplanarak çocuk COVID19 merkezi kuruldu. Pandemi süresince yatak sayıları değișebilmekle birlikte çocuk COVID-19 merkezimiz 12 yataklı klinik ve 6 yataklı Çocuk Yoğun Bakım Ünitesi olarak faaliyete başlamıştır. Klinik ve yoğun bakım ünitemizde pandemi yönetimi çerçevesinde gerekli teçhizat (3. basamak yoğun bakım hizmeti gerektiren ileri düzey solunum cihazları, portatif röntgen, ekokardiyografi vb.) ve ekipmanlar sağlanarak hastalarımızın tanı, takip ve tedavilerinde Çocuk Sağlığı ve Hastalıkları Anabilim Dalı öğretim üyeleri, araştırma görevlileri, deneyimli yardımcı sağlık personelleri ile büyük bir sağlık ekibi olarak tüm sağlık çalışanlarına COVID-19 ve kişisel koruyucu ekipmanların kullanımı, numune alma tekniği gibi konularda hizmet içi eğitimler verildikten sonra aktif olarak hizmet vermeye başlamış olup bu yazının yazıldığı tarih itibari ile de halen bu hizmet devam etmektedir. Ayrica pandemi hastanemizde şüpheli veya kesin COVID-19 tanılı gebeler için tahsis edilmiş doğum odası ve sezeryan için ameliyathanede mevcuttur. Bu bağlamda daha önceden çalışma düzeni belirlenmiş deneyimli ebe, yenidoğan hemşiresi, yenidoğan uzmanı ile Kadın Hastalıkları ve Doğum Anabilim Dalı ile koordineli bir şekilde gebelerin doğumları geçekleştirilmiş ve doğum sonrası yenidoğan takip ve tedavisi de merkezimizce yapılmıștır.

Çocuk COVID-19 merkezimize ayaktan başvurular izole edilmiş alanlarda bulunan COVID-19 polikliniği veya çocuk acil triyaj alanı aracılı̆̆ı ile, dıș merkezlerden yatış endikasyonu olan hasta kabulleri ise insan insan temasını önlemek için doğrudan COVID-19 kliniği veya COVID-19 yoğun bakım ünitesine yatış şeklinde gerçekleștirilmiştir. Hastalardan sürüntü numunelerini alınması, kan tetkiklerinin yapılması ve görüntüleme işlemleri COVID-19 şüphe veya hastalığı dışında kalan hastalardan bağımsız izole alanlarda hastanemiz enfeksiyon kontrol komitesi ve T.C. Sağlık Bakanlığ Pandemi Yönetim Rehberi (güncel rehberler takip edilerek) önerileri doğrultusunda yapılmıștır. Alınan numuneler yine öneriler doğrultusunda eğitimli yardımcl sağlık çalışanları aracılığı ile numune alma ekibi ve transfer ekiplerince salgının başlangıcında İl Sağlık Müdürlüğü Halk Sağlı̆̆ı Bulaşıcı Hastalıklar Birimine (Ankara Halk Sağlığı Laboratuvarında çalıştırılmak üzere), sonraki dönemlerde de hastanemiz mikrobiyoloji laboratuvarına ulaştırılarak sürüntü örneklerinden PCR testi çalıșılmaktadır. Hastaların ilk başvuru anından itibaren hasta verileri T.C. Sağlık Bakanlığı Halk Sağlığı Genel Müdürlüğü bünyesinde kurulan Halk Sağllğg Yönetim Sistemi (HSYS)'ye ve hastanemiz otomasyon sistemlerine kaydedilmektedir. Hastanemizden gönderilen örneklerde PCR pozitifliği saptanan hastalar ve onların temaslıları hastane sürveyans birimimiz tarafından tespit edilerek günlük olarak izleme alınmaktadır. Pandemi süresince her gün düzenli olarak belirli bir zaman aralığında yatan, taburcu edilen veya vefat eden hasta verileri İl Sağlık Müdürlüğüne bildirilmektedir. Pandeminin ilk dönemlerinde izolasyon amacı ile asemptomatik olgular da yatırılmaktaydı ancak ilerleyen dönemlerde bu vakaların takipleri izolasyon koşullarının uygun olması halinde aile hekimleri aracılı̆̆ ile ziyaret veya telefonla evde yakın izlem şeklinde gerçekleștirilmektedir. Sağlık Bakanlığının yayınladığı güncel rehberler doğrultusunda ağır vakalar hastaneye yatırılmaktadır. Hastanede veya evde takip gerektiren hasta seçimleri 
hastalığın ağırlığı, altta yatan veya eşlik eden hastalığa göre değişmekle birlikte hekimlerin bu hususlara göre karar vermesi önemlidir.

Çocuk COVID-19 klinik veya servis yatışı yapılan hastalardan rutin olarak kan tetkikleri alınarak, PA-AC grafisi çekildi. Hastaların takip sürecinde de hemogram (lenfopeni, lökositoz, trombositopeni), biyokimya (üre, kreatin, karaciğer enzimleri), ferritin, d-dimer, fibrinojen, CRP, prokalsitonin, kan gazı ve kardiyovasküler sistem değerlendirmesi (troponin, EKG) için istemler yapıldı. Tüm hastalara rutin olarak akciğer tomografisi istenmedi. Endikasyon dahilinde düşük doz akciğer tomografisi istenen vakaların değerlendirilmesinin de aynı radyoloji uzmanı tarafindan yapılması sağlandı Çocuk hastalarımızdaki COVID-19 takip ve tedavi planlaması, güncellenen Sağlık Bakanlığı Halk Sağlığı Müdürlüğü rehberi ile güncel literatürler ışığında yürütüldü. Yatan hastalarımızda hastalığa veya kullanılan tedavilere bağlı gelişebilecek komplikasyonlar açısından düzenli olarak ilgili branşlardan (başta çocuk kardiyoloji ve çocuk hematoloji olmak üzere) konsültasyonlar istendi. Yoğun bakım gerektiren hastalarımız için de mekanik ventilasyon (invaziv veya non-invaziv), CPAP, yüksek akımlı oksijen cihazı (HFO), balon maske, nazal oksijen desteği gibi solunum destekleri kullanıldı.

Dicle Üniversitesi Tıp Fakültesi Pandemi Hastanesi Çocuk COVID-19 merkezimize pandeminin ilk başladığı 17 Mart 2020 tarihinden, bu yazının yazıldığı 25 Eylül 2021 tarihine kadar şüpheli veya kesin tanılı 834 çocuk hasta kabul edilmiştir. Hastaların 294'ü (\%35,2) yatırılmış olup, tümünde COVID-19 PCR pozitifliği mevcuttu. Pandemi hastanemizin genelinde erişkin ve çocuk vakalar birlikte değerlendirildiğinde, 3336 erişkin hasta yatıșı ile birlikte hastanemiz özelinde çocuk hasta oranının \%8,09 olduğu tespit edildi. Mevcut verilerimizin dünyada ve ülkemizde bildirilen epidemiyolojik çalışmalar ile uyumlu olduğu görülmektedir. COVID-19 Çocuk Merkezimize yatırılan çocukların yaş ortalaması 96,2 \pm 14,1 ay idi (4-215 ay). Vakaların \%54,7'si erkek, $\% 45,3$ 'ü kız idi. Hastanede yatış süreleri ortalama 5,3 $\pm 2,1$ gün idi (1-54 gün, minimummaksimum). Yatan hastalarımızın 34'ü $(\% 11,5)$ yoğun bakım ünitesinde takip edildi. Yoğun bakım ünitesinde takip edilen 34 vakanın dokuzu $(\% 0,03)$ exitus oldu. Exitus olan vakalarımızın tümünde eşlik eden ağır hastalıklar (down sendromu, eisenmenger sendromu, kisa barsak sendromu, bronkopulmoner displazi, nöroblastom, metakromatik lökodistrofi ve akut lenfoblastik lösemi) mevcuttu. COVID-19 çocuk merkezimizde yatırılarak takip edilen 294 vakanın 46'sında $(\% 15,6)$ MIS-c tespit edildi. Bunların beşi yoğun bakım ünitesinde takip edildi ve tüm vakalar şifa ile taburcu edildi. Yatan hastaların 73'üne $(\% 24,8)$ akciğer tomografisi çekildi. Hastalara uygulanan tedaviler incelendiğinde; $11(\% 0,03)$ hastaya favipiravir, beş $(\% 0,01)$ hastaya lopinavir/ritonavir, bir $(\% 0,003)$ hastaya Tocilizumab, $35(\% 0,12)$ hastaya antikoagülan tedavi ve $11(\% 0,03)$ hastaya vasopressör tedavileri verildi ${ }^{17}$. $(\% 0,05)$ hastaya ise ileri solunum desteği (HFO, CPAP ve mekanik ventilasyon) uygulandı. Hiçbir hastanın hemodiyaliz ihtiyacı olmadı.

Zaman zaman vaka sayılarında azalma olsa da COVID-19 pandemisi tüm dünyada olduğu gibi ülkemizde de halen devam etmektedir. Hastalığı engelleyecek etkin bir ilaç da bulunamamıştır. Toplumsal aşılamanın etkin olarak yapılması ile yeni mutasyon/varyantların gelişmemesi, maske, mesafe ve hijyen koşullarının tam anlamıyla sağlanması dışında etkili ve güçlü argümanlarımız yoktur. Her ne kadar enfeksiyonun çocukluk çağında seyri hafif de olsa kronik hastalığı olan çocuklarda da mortal seyredebildiği hem hastane hem de ülkemiz ve dünya verilerinde görülmektedir. Ayrıca 
hastalığın uzun dönem etkileri de net olarak ortaya konulamamştır. $\mathrm{Bu}$ nedenlerle çocuklarımızın sağlığının korunması için aşılama hizmeti başta olmak üzere sağlık otoritelerinin bildirdiği toplumsal kurallara uymak önem arz etmektedir.

Çıkar Çatışması Beyanı: Yazarlar çıkar çatışması olmadığını bildirmişlerdir.

Finansal Destek: Bu çalıșma her hangi bir fon tarafından desteklenmemiștir.

Declaration of ConflictingInterests: The authors declare that they have no conflict of interest.

Financial Disclosure: No financial support was received.

\section{KAYNAKLAR}

1. Fabricant J. The early history of infectious bronchitis. Avian Dis 1998; 42: 648- 50.

2. Hamre D. Procknow JJ. A new virus isolated from the human respiratory tract. Proc Soc Exp Biol Med 1966; 121: 190-3.

3. Available at: https://www.who.int/emergencies/diseases/novel -coronavirus-2019/technical-guidance/namingthe-coronavirus-disease-(covid-2019)-and-thevirus-that-causes-it, Access date: 01.06.2021

4. King AMQ, Adams MJ, Cartens EB, Leiowitz EJ (eds.), Virus Taxonomy, the 9th report of the International Committee on Taxonomy of Viruses. Academic Press, San Diego, CA. doi:10.1016/B978$0-12-384684$

5. COVID-19 SARS-CoV-2 Enfeksiyonu Rehberi. T.C. Sağlık Bakanlığı, Halk Sağlığı Genel Müdürlüğü,14 Nisan 2020, Ankara.

6. Li D, Dawei W, Jianping D, et al. False-negative results of real-time reverse-transcriptase polymerase chain reaction for severe acute respiratory syndrome coronavirus 2: Role of deeplearning based CT diagnosis and insights frow two cases. Korean J Radiol 2020; 21: 505-8. doi: 10.3348/kjr.2020.0146.
7. Wang W, Xu Y, Gao R, et al. Detection of SARS-CoV2 in different types of clinical specimens. JAMA 2020; 323: 1843-4.

8. Pandemic COVID-19 and monitoring child patient. Kalkan İA, Aktar F. In: Coronavirus Disease 2019 (COVID-19): Turkey Perspective. Taşova Y, Çelen MK, eds. Hipokrat yayıncllık, Ankara 2020; 89-95. ISBN: 978-605-7874-63-4

9. Dong Y, Mo X, Hu Y, et al. Epidemiological characteristics of 2143 pediatric patients with 2019 coronavirus disease in China. Pediatrics 2020. pii: e20200702. https://doi.org/10.1542/peds.20200702

10. Huang C, Wang Y, Li X, Ren L, Zhao J, Hu Y, et al. Clinical features of patients infected with 2019 novel coronavirus in Wuhan, China. Lancet 2020; 395(10223): 497-506.

11. Liu J, Liu Y, Xiang P, et al. Neutrophil-tolymphocyte ratio predicts critical illness patients with 2019 novel coronavirus in the early stage. J Transl Med 2020; 18: 206.

12. Fan BE, Chong VCL, Chan SSW, et al. Hematologic parameters in patients with COVID-19 infection. Am J Hematol 2020; 95: E131-E134.

13. Chen ZM, Fu JF, Shu Q, et al. Diagnosis and treatment recommendations for pediatric respiratory infection caused by the 2019 novel coronavirus. World J Pediatr 2020; 16: 240-6.

14. Pediatric Intensive Care Society. PICS Statement: Increased number of reported cases of novel presentation of multi-system inflammatory disease. Available

https://picsociety.uk/wpcontent/uploads/2020/0 4/PICS-statement-re-novel-KD-C19- presentationv2-27042020.pdf. Access date: 27.07.2021

15. Center for Disease Control and Prevention, Center for Preparedness and Response: Multisystem Inflammatory Syndrome in children (MIS-C) associated with coronavirus disease 2019 (COVID19), clinician outreach and communication (COCA) webinar. Available at: https://emergency.cdc.gov/coca/calls/2020/callin fo_051920.asp?deliveryName=USCDC_1052DM28623 
$16 . \quad$ Erişim linki: https://covid19.saglik.gov.tr/Eklenti/40739/0/cov id-19rehbericocukhastayonetimivetedavipdf.pdf, Erişim Tarihi: 01.09.2021

17. Caparros-Gonzalez RA. Maternal and neonatal consequences of coronavirus COVID-19 infection during pregnancy: a scoping review. Rev Esp Salud Publica 2020; 94: e202004033.

18. De Rose DU, Piersigilli F, Ronchetti MP, et al. Novel coronavirus disease (COVID-19) in newborns and infants: what we know so far. Ital J Pediatr 2020; 46: 56.

19. Available https://www.covid19treatmentguidelines.nih.gov. Access date: 29.08.2021.

20. de Souza TG, Nadal JA, Nogueira RJN, Pereira RM, Brandao MB. Clinical manifestations of children with COVID-19: A systematic review. Pediatr Pulmonol 2020; 55: 1892-9.

21. Sankar J, Dhochak N, Kabra SK, Lodha R. COVID19 in children: Clinical approach and management. Indian J Pediatr 2020; 87: 433-42.

22. Grein J, Ohmagari N, Shin D, et al. Compassionate use of remdesivir for patients with severe Covid-19. N Engl J Med 2020; 382: 2327-36.
23. Chiotos $K$, Hayes $M$, Kimberlin DW, et al. Multicenter interim guidance on use of antivirals for children with coronavirus disease 2019/severe acute respiratory syndrome coronavirus 2 . J Pediatric Infect Dis Soc 2021; 10: 34-48.

24. WHO Solidarity Trial Consortium, et al. Repurposed antiviral drugs for Covid-19 - Interim WHO Solidarity Trial Results. N Engl J Med 2021; 384: 497-511.

25. Hernandez AV, Roman YM, Pasupuleti V, Barboza JJ, White CM. Hydroxychloroquine or chloroquine for treatment or prophylaxis of COVID-19: A living systematic review. Ann Intern Med 2020; 173: 28796.

26. Dulek DE, Fuhlbrigge RC, Tribble AC, et al. Multidisciplinary guidance regarding the use of immunomodulatory therapies for acute coronavirus disease 2019 in pediatric patients. J Pediatric Infect Dis Soc 2020; 9: 716-37.

27. Lu Y, Li Y, Deng W, et al. Symptomatic infection is associated with prolonged duration of viral shedding in mild coronavirus disease 2019: A retrospective study of 110 children in Wuhan. Pediatr Infect Dis J 2020; 39: e95-e99. 